Фармацевтична технологія, біофармація, гомеопатія Pharmaceutical technology, biopharmacy, homeopathy

Фармацевтична технологія, біофармація, гомеопатія ФАРМАЦЕВТИЧНИЙ ЧАСОПИС

http://ojs.tdmu.edu.ua/index.php/pharm-chas

УДК 615.453.6:664.135:66.068

DOI https://doi.org/10.11603/2312-0967.2021.2.12056

\title{
ПОРІВНЯЛЬНІ ДОСЛІДЖЕННЯ ДЕЯКИХ МАРОК ЛАКТОЗИ ЯК НАПОВНЮВАЧІВ ДЛЯ ПРЯМОГО ПРЕСУВАННЯ ТАБЛЕТОК
}

\author{
М. Б. Демчук, Т. А. Грошовий, О. М. Леськів, Н. В. Маланчук \\ Тернопільський національний медичний університет імені І. Я. Горбачевського мОз \\ України \\ pavljukm@tdmu.edu.ua
}

ІНФОРМАЦІЯ

Надійшла до редакції / Received: 12.03.2021

Після доопрацювання / Revised:

24.03.2021

Прийнято до друку / Accepted:

25.03.2021

\section{Ключові слова:}

таблетки;

пряме пресування;

лактоза;

MicroceLac ${ }^{\circledR} 100$;

Ludipress $^{\circledR}$;

Cellactose ${ }^{\circledR} 80$;

Pharmatose ${ }^{\circledR}$ DCL-21.
АНОТАЦІЯ

Мета роботи. Вивчення впливу різної кількості деяких марок лактози на зміну технологічних параметрів модельних таблеток, отриманих прямим пресуванням. Матеріали і методи. В роботі використовували лактози моногідрат 200/25, MicroceLac ${ }^{\circledR} 100$, Ludipress $^{\circledR}$, Cellactose ${ }^{\circledR} 80$, Pharmatose $^{\circledR}$ DCL-21. Як модельні об'єкти-речовини використовували кислоту ацетилсаліцилову і меторорміну гідрохлорид. Маси для таблетування оцінювали за показниками насипної густини, густини після усадки, плинності, коефіцієнтом Гауснера. Таблетки отримували методом прямого пресування на лабораторному таблетпресі та контролювали їхні фрармако-технологічні властивості.

Результати й обговорення. Досліджено вплив різної кількості лактози моногідрату 200/25, MicroceLac ${ }^{\circledR} 100$, Ludipress ${ }^{\circledR}$, Cellactose ${ }^{\circledR} 80$, Pharmatose ${ }^{\circledR}$ DCL-21 на зміну технологічних показників маси для таблетування з кислотою ацетилсаліциловою. Найкращу сипучість та значення коефіцієнта Гауснера мають ті маси, які містили Ludipress у кількості $12 \%$, Cellactose 80 у кількості 8 або 10\%, Pharmatose DCL-21 у кількості $8 \%$. Стійкість таблеток до роздавлювання та стираність покращувало введення Pharmatose ${ }^{\circledR}$ DCL-21 або MicroceLac ${ }^{\circledR} 100$. Використання будь-якого типу лактози забезпечувало швидке розпадання таблеток кислоти ацетилсаліцилової.

Порошок меторорміну гідрохлориду характеризується орармакотехнологічними показниками, що унеможливлюють його пряме пресування без допоміжних речовин. Кращі значення стійкості таблетокдо роздавлювання і стираність таблеток отримано при введенні у їхній склад 10 \% Cellactose ${ }^{\circledR} 80$ або 8 \% MicroceLac ${ }^{\circledR} 100$.

Висновки. Досліджено вплив різної кількості лактози моногідрату 200/25, MicroceLac $^{\circledR}$ 100, Ludipress ${ }^{\circledR}$, Cellactose ${ }^{\circledR}$ 80, Pharmatose ${ }^{\circledR}$ DCL-21 на зміну технологічних показників таблеток кислоти ацетилсаліцилової, а також меторорміну гідрохлориду, отриманих прямим пресуванням. Покращення технологічних параметрів маси для таблетування та таблеток із кислотою ацетилсаліциловою можна досягти при використанні Ludipress у кількості 12 \% від маси таблетки, Cellactose 80 у кількості $10 \%$, Pharmatose DCL-21 у кількості $8 \%$. Таблетки метформіну з бажаними значеннями стійкості до роздавлювання і стираності отримано при введенні у їх склад $10 \%$ Cellactose $^{\circledR} 80$ або 8 \% MicroceLac ${ }^{\circledR} 100$.

ISSN 2312-0967. Pharmaceutical review. 2021. № 2 
Фармацевтична технологія, біофармація, гомеопатія Pharmaceutical technology, biopharmacy, homeopathy

Вступ. Серед відомих методів виробництва таблетованих лікарських фрорм вигідно відрізняється від інших метод прямого пресування. Переваги прямого пресування, а саме мінімізація вартості та підвищення ефективності виробництва стимулюють фрармацевтичні компанії використовувати цей метод у виробництві таблеток [1]. Однак активних фрармацевтичних інгредієнтів (АФІ), придатних до прямого пресування, у таблетки обмаль. Оскільки основними вимогами до властивостей АФІ, які б забезпечували їхнє безпосереднє пресування, $€$ ізодіаметрична фрорма кристалів, добра сипучість і спресованість, низька адгезійна здатність до прес-інструменту. Проте існує ряд технологічних прийомів, за допомогою яких можна отримати таблетки прямим пресуванням [2]. Важливу роль при цьому відіграють технологічні властивості допоміжних речовин (ДР), їхня кількість у складі таблеток тощо.

До ДР, які використовують при прямому пресуванні таблеток, встановлюють додаткові вимоги щодо доброї плинності, високої здатності до зв'язування, а також можливості покращувати міцність та розпадання таблеток. Виконати ці вимоги за допомогою введення однієї ДР не можливо. Проте, використання багатьох ДР у складі таблеток може призвести до проблем із сегрегацією чи навіть несумісністю, які можуть виникнути між АФІ та використовуваними ДР. Виробники ексципієнтів докладають значні зусилля на дослідження та розробку нових мультифункціональних ДР [3, 4].

На фрармацевтичному ринку ДР представлено широкий асортимент наповнювачів для використання у технології прямого пресування. Одними із найпоширеніших наповнювачів $€$ лактоза та комбіновані продукти на її основі. Це зумовлено їхньою високою стабільністю, незначною гігроскопічністю, відносно низькою вартістю та широкою фрункціональністю [5-7]. Марки лактози відрізняються фрормою і розмірами частинок, фрракційним складом, характеристиками плинності та спресованості. Лактоза зустрічається у $\alpha$ та $\beta$ фрормах, що мають різну температуру плавлення, розчинність та твердість. Відомо, що різні марки лактози мають різні грануляційні та компресійні власти-

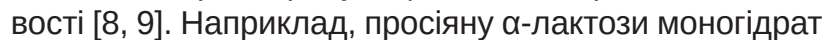
використовують при прямому пресуванні, тоді як розмелену а-лактоза моногідрат через погану спресованість використовують у вологому гранулюванні [10]. Лактозу та безводну лактозу, отримані розпилювальним висушуванням, рекомендують для сухого гранулювання та прямого пресування завдяки відмінній сипучості та здатності до спресовування [11].

Мета роботи - порівняльні дослідження деяких торгових марок лактози, вивчення впливу їхньої кількості на зміну технологічних параметрів модельних таблеток, отриманих прямим пресуванням.

Матеріали і методи. Для досліджень обрано декілька зразків лактози, зокрема лактози моногідрат
200/25 (Alpavit Kaserei Champignon Hofmeister), MicroceLac $^{\circledR} 100$ (Meggle GmbH), Ludipress ${ }^{\circledR}$ (BASF), Cellactose $^{\circledR}$ 80® (Meggle $\mathrm{GmbH}$ ), Pharmatose ${ }^{\circledR}$ DCL$21 \circledR(D M V$ International).

MicroceLac ${ }^{\circledR} 100$, отримують розпилювальним висушуванням суміші а-лактози моногідрату та мікрокристалічної целюлози (МКЦ). MicroceLac ${ }^{\circledR} 100$ використовують у технології прямого пресування, забезпечуючи високу міцність та однорідність маси таблеток [12, 13]. Фармако-технологічні характеристики MicroceLac ${ }^{\circledR} 100$ та інших досліджуваних марок лактози представлені у таблиці 1.

Ludipress $^{\circledR}$ представлений у фрормі кулеподібних конгломератів, що містять лактози моногідрат, Kollidon 30 та Kollidon CL. Ludipress ${ }^{\circledR}$ - відмінний екципієнт завдяки гарній плинності, відсутності сегрегації з АФІ, високій зв'язувальній здатності, а вміст Kollidon CL забезпечує швидке розпадання таблеток $[14,15]$.

Cellactose ${ }^{\circledR} 80$ отримують розпилювальним висушуванням суміші $\alpha$-лактози моногідрату та порошкової целюлози. Cellactose ${ }^{\circledR} 80$ у складі таблеток, отриманих прямим пресуванням, зумовлює кращу стійкість до роздавлювання, менший час розпадання і кращі смакові якості $[16,17]$.

Pharmatose ${ }^{\circledR}$ DCL-21 являє собою безводну кристалічну ß-лактозу, отриману роликовим висушуванням, яка характеризується доброю плинністю, високою здатністю до спресовуваності. Перевагою Pharmatose ${ }^{\circledR}$ DCL-21 $є$ можливість іï̈ введення у таблетки із вологочутливими АФІ $[18,19]$.

Для експериментальних досліджень як модельні речовини обрали кислоту ацетилсаліцилову і метфрорміну гідрохлорид. Кислота ацетилсаліцилова представлена частинками ізодіаметричної форми. Порошок характеризується такими показниками: на-

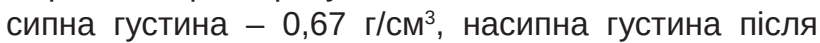
усадки - 0,86 г/см ${ }^{3}$ кут природного укосу $-38^{\circ}$, сипучість порошку - 7,8 с/100 г. Технологічні показники кислоти ацетилсаліцилової свідчать про можливість ії використання як модельного зразка для отримання таблеток методом прямого пресування.

Як приклад іншої модельної речовини для експериментального дослідження обрано порошок метфрорміну, що характеризується поганою плинністю, вільна насипна густина складає 0,454 г/мл, насипна густина після усадки - 0,74 г/мл. Порошок містить частинки розміром від 50 до 250 мкм, із часткою дрібних частинок із розміром понад 50 мкм - 53,0 \%, що свідчить про його здатність до грудкування. Тобто, застосування прямого пресування вимагатиме використання ДР з метою корекції фрармако-технологічних показників маси для таблетування, що містить метформін.

На ринку представлені таблетовані лікарські форми, що містять різне дозування кислоти ацетилсаліцилової від 75 до 500 мг, також представлено таблет-

ISSN 2312-0967. Фармацевтичний часопис. 2021. № 2 
Фармацевтична технологія, біофармація, гомеопатія Pharmaceutical technology, biopharmacy, homeopathy

Таблиця 1

Фармако-технологічні характеристики різних торгових марок лактози

\begin{tabular}{|l|c|c|c|c|l|}
\hline $\begin{array}{c}\text { Фармако-технологічні } \\
\text { характеристики }\end{array}$ & $\begin{array}{c}\text { Насипна } \\
\text { густина, г/см }\end{array}$ & $\begin{array}{c}\text { Насипна } \\
\text { густина після } \\
\text { усадки, г/см }{ }^{3}\end{array}$ & $\begin{array}{c}\text { Кут } \\
\text { природного } \\
\text { укосу, }\end{array}$ & $\begin{array}{c}\text { Індекс } \\
\text { Гауснера }\end{array}$ & $\begin{array}{c}\text { Розподіл частинок } \\
\text { за розмірами }\end{array}$ \\
\hline $\begin{array}{l}\text { Лактози моногідрат } \\
\text { 200/25 }\end{array}$ & 0,51 & 0,77 & 38 & 1,26 & $\begin{array}{l}<38 \mu \mathrm{m}<=58 \% \\
<53 \mu \mathrm{m}: \leq 43 \% \\
<75 \mu \mathrm{m}: \geq 25 \% \\
<106 \mu \mathrm{m}: \geq 12 \% \\
<125 \mu \mathrm{m} \geq 10 \%\end{array}$ \\
\hline MicroceLac $^{\circledR} 100$ & 0,46 & 0,58 & 34 & 1,26 & $\begin{array}{l}<32 \mu \mathrm{m}: \text { NMT } 15 \% \\
<160 \mu \mathrm{m}: 45-70 \% \\
<250 \mu \mathrm{m}: \text { NLT90\% }\end{array}$ \\
\hline Ludipress $^{\circledR}$ & 0,55 & 0,65 & 30 & 1,20 & $\begin{array}{l}<263 \mu \mathrm{m}: 15 \% \\
<200 \mu \mathrm{m}: 40-60 \% \\
<400 \mu \mathrm{m}: 90 \%\end{array}$ \\
\hline Cellactose $^{\circledR} 80$ & 0,38 & 0,50 & 34 & 1,24 & $\begin{array}{l}<32 \mu \mathrm{m}<=20 \% \\
<160 \mu \mathrm{m} 35-65 \% \\
<200 \mu \mathrm{m}>=80 \%\end{array}$ \\
\hline $\begin{array}{l}\text { Pharmatose } \\
\text { DCL-21 }\end{array}$ & 0,68 & 0,88 & 36,9 & 1,27 & $\begin{array}{l}<45 \mu \mathrm{m}: 15 \% \\
<150 \mu \mathrm{m}: 50 \% \\
<250 \mu \mathrm{m}: 85 \%\end{array}$ \\
\hline
\end{tabular}

Примітка: фрармако-технологічні характеристики марок лактози наведено за даними виробників відповідних торгових марок.

ки меторорміну із дозуванням від 500 до 1000 мг із поєднанням різних ДР, однак нашою метою було дослідження впливу обраних зразків лактози та їхньої кількості на зміну технологічних параметрів таблеток, із вказаних модельних речовин, отриманих прямим пресуванням.

Маси для таблетування оцінювали за показниками насипної густини, густини після усадки, плинності, коефіцієнта Гауснера. Таблетки пресували на лабораторному таблетпресі масою 0,3 г з діаметром 8 мм та контролювали за такими показниками, як стійкість до роздавлювання на приладі Tablet Tester (Electrolab Company, India), стираність на приладі Friability Tester (Electrolab Company, India) та час розпадання на приладі Desintegration Tester (Electrolab Company, India) [20].

Результати й обговорення. На першому етапі дослідження вивчали вплив різних зразків лактози та їхньої кількості на фрармако-технологічні властивості таблеток кислоти ацетилсаліцилової, отриманих методом прямого пресування.

Модельні суміші містили 250 мг кислоти ацетилсаліцилової, лактозу у кількості 8 \%, $10 \%$ або $12 \%$, кислоту стеаринову - 1 \%. Доводили до необхідної маси МКЦ 102. Склад модельних сумішей наведено в таблиці 2. Результати дослідження маси для таблетування та готових таблеток, що містили кислоту ацетилсаліцилову, наведено в таблиці 3.

Досліджено фрармако-технологічні показники маси для таблетування 3 кислотою ацетилсаліциловою.
Найкращу сипучість мали маси, які містили Ludipress у кількості $12 \%$, Cellactose 80 у кількості 8 або $10 \%$, Pharmatose DCL-21 у кількості 8 \%. Значення коесріцієнта Гауснера знаходяться в межах від 1,05 до 1,17, що свідчить про дуже добру плинність порошку. Задовільні значення сипучості (коефіцієнт Гауснера 1,17-1,22) отримано для маси, що містили лактозу моногідрат 200/25 та MicroceLac ${ }^{\circledR} 100$.

Одним із критичних показників для таблеток кислоти ацетилсаліцилової є їхня стійкість до роздавлювання. Так, введення Pharmatose ${ }^{\circledR}$ DCL-21 у кількості 8-12 \% забезпечує міцність таблеток - 35 Н. Незначно покращується стійкість таблеток до роздавлювання при введенні до складу таблеток 12 \% MicroceLac ${ }^{\circledR} 100$.

Таблетки кислоти ацетилсаліцилової досліджували за критерієм стійкості до стирання. При введенні до складу таблеток лактози моногідрату 200/25 або Ludipress ${ }^{\circledR}$ у кількості 8 \% таблетки не проходили випробування на стираність. Збільшення вмісту цих ДР до 10 або 12 \% суттєво покращувало стираність таблеток, яка зменшувалася до 0,3-0,4%. Стираність таблеток кислоти ацетилсаліцилової 3 MicroceLac ${ }^{\circledR}$ 100 або Pharmatose ${ }^{\circledR}$ DCL-21 знаходилася у межах 0,55-0,65 \%, що відповідало вимогам ДФУ. За даними таблиці 3, введення до складу будь-якого типу лактози скорочує час розпадання таблеток, що містили кислоту ацетилсаліцилову до 2 хв.

Тобто, у випадку використання зразків лактози для отримання таблеток із кислотою ацетилсаліциловою,

ISSN 2312-0967. Pharmaceutical review. 2021. № 2 
Фармацевтична технологія, біофармація, гомеопатія Pharmaceutical technology, biopharmacy, homeopathy

\section{Таблиця 2}

Склад модельних сумішей, що містили кислоту ацетилсаліцилову

\begin{tabular}{|c|c|c|c|c|c|c|c|c|}
\hline $\begin{array}{l}\text { № } \\
\text { cepiï }\end{array}$ & $\begin{array}{c}\text { Кислота ацетил- } \\
\text { саліцилова, \% }\end{array}$ & $\begin{array}{c}\text { Лактози } \\
\text { моногідрат } \\
\text { 200/25, \% }\end{array}$ & $\begin{array}{l}\text { Micro- } \\
\text { ceLac }^{\circledR} \\
100, \%\end{array}$ & $\begin{array}{l}\text { Ludip- } \\
\text { ress }^{\circledR} \text { \% }\end{array}$ & $\begin{array}{c}\text { Cellac- } \\
\text { tose }{ }^{\circledR} 80, \\
\%\end{array}$ & $\begin{array}{c}\text { Pharmatose }^{\circledR} \\
\text { DCL-21, } \\
\%\end{array}$ & $\begin{array}{c}\text { МКЦ } \\
102 \\
\%\end{array}$ & $\begin{array}{c}\text { Кислота } \\
\text { стеаринова, } \\
\%\end{array}$ \\
\hline 1 & 83,3 & 8 & - & - & - & - & 7,7 & 1 \\
\hline 2 & 83,3 & 10 & - & - & - & - & 5,7 & 1 \\
\hline 3 & 83,3 & 12 & - & - & - & - & 3,7 & 1 \\
\hline 4 & 83,3 & - & 8 & - & - & - & 7,7 & 1 \\
\hline 5 & 83,3 & - & 10 & - & - & - & 5,7 & 1 \\
\hline 6 & 83,3 & - & 12 & - & - & - & 3,7 & 1 \\
\hline 7 & 83,3 & - & - & 8 & - & - & 7,7 & 1 \\
\hline 8 & 83,3 & - & - & 10 & - & - & 5,7 & 1 \\
\hline 9 & 83,3 & - & - & 12 & - & - & 3,7 & 1 \\
\hline 10 & 83,3 & - & - & - & 8 & - & 7,7 & 1 \\
\hline 11 & 83,3 & - & - & - & 10 & - & 5,7 & 1 \\
\hline 12 & 83,3 & - & - & - & 12 & - & 3,7 & 1 \\
\hline 13 & 83,3 & - & - & - & - & 8 & 7,7 & 1 \\
\hline 14 & 83,3 & - & - & - & - & 10 & 5,7 & 1 \\
\hline 15 & 83,3 & - & - & - & - & 12 & 3,7 & 1 \\
\hline
\end{tabular}

\section{Таблиця 3}

Результати срармако-технологічних досліджень маси для таблетування та таблеток, що містили кислоту ацетилсаліцилову

\begin{tabular}{|c|r|c|c|r|c|c|c|}
\hline $\begin{array}{c}\text { № } \\
\text { серії }\end{array}$ & $\begin{array}{c}\text { Плинність, } \\
\text { г/с }\end{array}$ & $\begin{array}{c}\text { Насипна } \\
\text { густина, г/ } \\
\text { см}^{3}\end{array}$ & $\begin{array}{c}\text { Насипна } \\
\text { густина після } \\
\text { усадки, г/см }\end{array}$ & $\begin{array}{c}\text { Коеріцієнт } \\
\text { Гауснера }\end{array}$ & $\begin{array}{c}\text { Стійкість до } \\
\text { роздавлювання, } \\
\text { H }\end{array}$ & $\begin{array}{c}\text { Розпадання, } \\
\text { с }\end{array}$ & Стираність, \% \\
\hline 1 & 2,5 & 0,649 & 0,785 & 1,21 & 25,6 & 3,0 & 2,33 \\
\hline 2 & 7,5 & 0,683 & 0,791 & 1,16 & 24,4 & 5,0 & 0,50 \\
\hline 3 & 3,8 & 0,688 & 0,841 & 1,22 & 24,9 & 7,0 & 0,40 \\
\hline 4 & 7,5 & 0,680 & 0,831 & 1,22 & 24,4 & 6,0 & 0,55 \\
\hline 5 & 9,4 & 0,718 & 0,837 & 1,17 & 26,3 & 8,0 & 0,55 \\
\hline 6 & 10,7 & 0,715 & 0,834 & 1,17 & 33,2 & 50,0 & 0,60 \\
\hline 7 & 9,3 & 0,746 & 0,785 & 1,05 & 32,9 & 10,0 & 5,16 \\
\hline 8 & 11,1 & 0,708 & 0,782 & 1,11 & 26,3 & 5,0 & 0,30 \\
\hline 9 & 12,5 & 0,682 & 0,790 & 1,16 & 31,9 & 15,0 & 0,35 \\
\hline 10 & 13,3 & 0,753 & 0,836 & 1,11 & 25,5 & 10,0 & 0,70 \\
\hline 11 & 13,2 & 0,681 & 0,789 & 1,16 & 26,2 & 5,0 & 0,54 \\
\hline 12 & 10,2 & 0,714 & 0,833 & 1,17 & 29,7 & 7,0 & 0,90 \\
\hline 13 & 13,2 & 0,710 & 0,828 & 1,17 & 35,3 & 17,0 & 0,59 \\
\hline 14 & 10,9 & 0,748 & 0,831 & 1,11 & 26,1 & 20,0 & 0,65 \\
\hline 15 & 11,8 & 0,749 & 0,832 & 1,11 & 34,0 & 70,0 & 0,60 \\
\hline
\end{tabular}

фрармако-технологічні показники якої відповідають вимогам до прямого пресування, покращення технологічних параметрів маси для таблетування та таблеток можна досягти при використанні Ludipress у кількості 12 \% від маси таблетки, Cellactose 80 у кількості $10 \%$, Pharmatose DCL-21 у кількості $8 \%$.

На наступному етапі дослідження вивчали вплив різної кількості обраних зразків лактози на фрармако-

ISSN 2312-0967. Фармацевтичний часопис. 2021. № 2 
технологічні властивості таблеток метфрорміну гідрохлориду, отриманих методом прямого пресування.

Модельні суміші містили метфрормін, лактозу у кількості 8 \%, $10 \%$ або $12 \%$, магнію стеарат - 1 \%, тальку - 2 \%. Доводили до необхідної маси МКЦ 102. Склад модельних сумішей наведено в таблиці 4. Та-
Фармацевтична технологія, біофармація, гомеопатія Pharmaceutical technology, biopharmacy, homeopathy блетки пресували на лабораторному таблетпресі масою 0,3 г 3 діаметром 8 мм. Результати дослідження таблеток меторорміну наведено в таблиці 5.

Таблетки меторорміну без додавання лактози чи інших ДР були надзвичайно крихкими, ламкими та не проходили випробування на міцність, тобто отримати

Таблиця 4

Склад модельних сумішей, що містили метфрорміну гідрохлорид

\begin{tabular}{|c|c|c|c|c|c|c|c|c|c|}
\hline $\begin{array}{l}\text { № } \\
\text { cepiï }\end{array}$ & $\begin{array}{l}\text { Метфрор- } \\
\text { мін, \% }\end{array}$ & $\begin{array}{c}\text { Лактози } \\
\text { моногідрат } \\
\text { 200/25, \% } \\
\end{array}$ & $\begin{array}{c}\text { Microcelac }^{\circledR} \\
100 \\
\%\end{array}$ & $\begin{array}{c}\text { Ludipress }^{\circledR}, \\
\%\end{array}$ & $\begin{array}{c}\text { Cellactose }^{\circledR} \\
80, \\
\%\end{array}$ & $\begin{array}{c}\text { Pharmatose }^{\circledR} \\
\text { DCL-21, } \\
\%\end{array}$ & $\begin{array}{c}\text { МКЦ } \\
102, \\
\%\end{array}$ & $\begin{array}{c}\text { Тальк, } \\
\%\end{array}$ & $\begin{array}{c}\text { Магнію } \\
\text { стеарат, } \\
\%\end{array}$ \\
\hline 1 & 50 & 8 & - & - & - & - & 39 & 2 & 1 \\
\hline 2 & 50 & 10 & - & - & - & - & 37 & 2 & 1 \\
\hline 3 & 50 & 12 & - & - & - & - & 35 & 2 & 1 \\
\hline 4 & 50 & - & 8 & - & - & - & 39 & 2 & 1 \\
\hline 5 & 50 & - & 10 & - & - & - & 37 & 2 & 1 \\
\hline 6 & 50 & - & 12 & - & - & - & 35 & 2 & 1 \\
\hline 7 & 50 & - & - & 8 & - & - & 39 & 2 & 1 \\
\hline 8 & 50 & - & - & 10 & - & - & 37 & 2 & 1 \\
\hline 9 & 50 & - & - & 12 & - & - & 35 & 2 & 1 \\
\hline 10 & 50 & - & - & - & 8 & - & 39 & 2 & 1 \\
\hline 11 & 50 & - & - & - & 10 & - & 37 & 2 & 1 \\
\hline 12 & 50 & - & - & - & 12 & - & 35 & 2 & 1 \\
\hline 13 & 50 & - & - & - & - & 8 & 39 & 2 & 1 \\
\hline 14 & 50 & - & - & - & - & 10 & 37 & 2 & 1 \\
\hline 15 & 50 & - & - & - & - & 12 & 35 & 2 & 1 \\
\hline
\end{tabular}

Таблиця 5

Результати срармако-технологічних досліджень таблеток, що містили меторорміну гідрохлорид

\begin{tabular}{|c|c|c|c|}
\hline № серії & $\begin{array}{c}\text { Стійкість до роздавлювання, } \\
\text { H }\end{array}$ & Розпадання, с & Стираність, $\%$ \\
\hline 1 & 31,0 & 10 & 1,34 \\
\hline 2 & 27,9 & 7 & 1,41 \\
\hline 3 & 23,9 & 9 & 0,48 \\
\hline 4 & 45,5 & 10 & 0,83 \\
\hline 5 & 40,0 & 7 & 0,83 \\
\hline 6 & 31,6 & 9 & 0,66 \\
\hline 7 & 46,3 & 9 & 0,90 \\
\hline 8 & 42,3 & 9 & 11,25 \\
\hline 9 & 29,5 & 8 & 0,27 \\
\hline 10 & 49,5 & 7 & 0,37 \\
\hline 11 & 52,1 & 10 & 0,60 \\
\hline 12 & 50,7 & 12 & 1,47 \\
\hline 13 & 39,1 & 9 & 0,77 \\
\hline 14 & 35,0 & 8 & 0,94 \\
\hline 15 & 30,4 & 10 & \\
\hline
\end{tabular}

ISSN 2312-0967. Pharmaceutical review. 2021. № 2 
Фармацевтична технологія, біофармація, гомеопатія Pharmaceutical technology, biopharmacy, homeopathy

таблетки меторорміну прямим пресуванням без додавання раціональних ДР не можливо. Введення ДР, зокрема обраних зразків лактози, значно покращує технологічні показники таблеток меторорміну.

Стійкість таблеток меторорміну до роздавлювання значно покращується при введенні до їхнього складу Cellactose $^{\circledR} 80$ або MicroceLac ${ }^{\circledR} 100$ (див. табл. 5). Ранжований ряд переваг для досліджуваних видів лактоз за їхнім впливом на стійкість таблеток до роздавлювання має такий вигляд: Cellactose ${ }^{\circledR} 80$ (10\%) $>$ Cellactose $^{\circledR} 80(12 \%)>$ Cellactose $^{\circledR} 80(8 \%)>$ Ludipress $^{\circledR}(8 \%)>$ MicroceLac $^{\circledR} 100(8 \%)>$ Ludipress $^{\circledR}$ $(10 \%)>$ MicroceLac $^{\circledR} 100(10 \%)>$ Pharmatose $^{\circledR}$ DCL$21(8 \%)>$ Pharmatose $^{\circledR}$ DCL-21 $(10 \%)>$ MicroceLac ${ }^{\circledR}$ $100(12 \%)>$ лактози моногідрат (8 \%) > Pharmatose $^{\circledR}$ DCL-21 (12 \%) > Ludipress ${ }^{\circledR}(12 \%)>$ лактози моногідрат ( $10 \%$ та $12 \%)$.

Показники стираності таблеток метформіну, що містили різні види лактози, значно відрізнялися. Найстійкішими до стирання були таблетки, що містили Cellactose $^{\circledR}$ 80. При вмісті $8 \%$ Cellactose ${ }^{\circledR} 80$ показники стираності таблеток були мінімальні і складали 0,27\%, зі збільшенням вмісту Cellactose ${ }^{\circledR} 80$ до $12 \%$ значення стираності збільшувалося до 0,6 \%.

Стираність коливалася у межах 0,47 до 0,83 \% при збільшенні кількості MicroceLac ${ }^{\circledR} 100$ від 8 до $12 \%$. Найменш стійкими до стирання були таблетки, що містили Pharmatose ${ }^{\circledR}$ DCL-21 у кількості 8 \%. Таблетки меторорміну, що містили $12 \%$ лактози моногідрату aбо Ludipress ${ }^{\circledR}$, не пройшли випробування на стираність.

Час розпадання таблеток меторорміну незалежно від типу чи вмісту лактози складав менше 15 с, що зумовлено також високою розчинністю метфрорміну.

Введення у склад таблеток метформіну деяких торгових марок лактози дає можливість отримати таблетки прямим пресуванням, з бажаними технологічними показниками. Оптимальні значення стійкості таблеток до роздавлювання і стираність таблеток отримано при введенні в їхній склад $10 \%$ Cellactose $^{\circledR}$ 80 або 8 \% MicroceLac ${ }^{\circledR} 100$.

Висновки. Досліджено вплив різної кількості лактози моногідрату, Microcelac ${ }^{\circledR} 100$, Ludipress $^{\circledR}$, Cellactose $^{\circledR} 80$, Pharmatose ${ }^{\circledR}$ DCL-21 на зміну технологічних показників таблеток кислоти ацетилсаліцилової, метформіну гідрохлориду, отриманих прямим пресуванням. Покращення технологічних параметрів маси для таблетування та таблеток із кислотою ацетилсаліциловою, можна досягти при використанні Ludipress у кількості $12 \%$ від маси таблетки або Cellactose 80 у кількості $10 \%$ чи Pharmatose DCL-21 у кількості $8 \%$. Таблетки метформіну з бажаними значеннями стійкості до роздавлювання і стираності отримано при введенні в їхній склад $10 \%$ Cellactose ${ }^{\circledR}$ 80 або $8 \%$ MicroceLac $® 100$.

Експериментальні дослідження засвідчують, що комбіновані наповнювачі в технології прямого пресування часто $є$ більш ефективними за впливом на технологічні показники таблеток. Проведені дослідження започаткували обґрунтування необхідності створення вітчизняного комплексного наповнювача на заміну імпортним ДР.

Конфрлікт інтересів: відсутній.

Conflicts of interests: authors have no conflict of interest to declare.

\title{
COMPARATIVE RESEARCH OF SOME BRANDS OF LACTOSE AS FILLERS FOR DIRECT COMPRESSION OF TABLETS
}

\author{
M. B. Demchuk, T. A. Hroshovyi, O. M. Leskiv, N. V. Malanchuk \\ I. Horbachevsky Ternopil National Medical University \\ pavljukm@tdmu.edu.ua
}

The aim of the work. Studying of the influence different amounts of some brands of lactose on the change of technological parameters of model tablets obtained by direct compression.

Materials and Methods. Lactose monohydrate 200/25, MicroceLac ${ }^{\circledR}$ 100, Ludipress ${ }^{\circledR}$, Cellactose ${ }^{\circledR} 80$, Pharmatose $₫$ DCL-21 were used in the work. Acetylsalicylic acid and metformin hydrochloride were used as model objects. The mass for tableting was evaluated by bulk density, tapped density, flowability and Hausner coefficient. The tablets were obtained by direct compression on a laboratory tablet press and monitored their pharmaco-technological properties.

Results and Discussion. The influence of different amounts of lactose monohydrate 200/25, MicroceLac $(100$, Ludipress ${ }^{\circledR}$, Cellactose ${ }^{\circledR} 80$, Pharmatose ${ }^{\circledR}$ DCL-21 on the change of technological parameters of mass with acetylsalicylic acid for tableting was studied. The mass containing $12 \%$ Ludipress $^{\circledR}, 8$ or $10 \%$ Cellactose $^{\circledR} 80$ or $8 \%$ Pharmatose ${ }^{\circledR}$ DCL21 has the best flowability and Hausner coefficient. The introduction of Pharmatose ${ }^{\circledR}$ DCL-21 or MicroceLac 100 improved tablet hardness and friability. The use of lactose of any type provided rapid disintegration of acetylsalicylic acid tablets. Metformin hydrochloride powder is characterized by technological parameters that make it impossible for direct compression without of excipients. The hardness and friability of metformin tablets is significantly improved with the introduction of $10 \%$ Cellactose ${ }^{\circledR} 80$ or $8 \%$ MicroceLac $^{\circledR} 100$.

ISSN 2312-0967. Фармацевтичний часопис. 2021. № 2 
Conclusions. The influence of different amounts of lactose monohydrate 200/25, MicroceLac ${ }^{\circledR} 100$, Ludipress ${ }^{\circledR}$, Cellactose ${ }^{\circledR}$ 80 , Pharmatose ${ }^{\circledR}$ DCL-21 on the change of technological parameters of acetylsalicylic acid tablets, as well as metformin hydrochloride tablets obtained by direct compression was studied. Improvement of the technological parameters of mass for tableting and tablets with acetylsalicylic acid can be achieved with the use of Ludipress ${ }^{\circledR}$ in the amount of $12 \%$ by weight of the tablet or Cellactose $\AA 80$ in the amount of $10 \%$ or Pharmatose ${ }^{\circledR}$ DCL-21 in the amount of $8 \%$. Metformin tablets with the desired values of hardness and friability were obtained by introducing $10 \%$ Cellactose ${ }^{\circledR} 80$ or $8 \%$ MicroceLac ${ }^{\circledR} 100$ into their composition.

Key words: tablets; direct compression; lactose; MicroceLac ${ }^{\circledR} 100$; Ludipress ${ }^{\circledR}$; Cellactose ${ }^{\circledR} 80^{\prime}$ Pharmatose ${ }^{\circledR}$ DCL-21.

\title{
СРАВНИТЕЛЬНОЕ ИССЛЕДОВАНИЕ НЕКОТОРЫХ МАРОК ЛАКТОЗЫ КАК НАПОЛНИТЕЛЕЙ ДЛЯ ПРЯМОГО ПРЕССОВАНИЯ ТАБЛЕТОК
}

\author{
М. Б. Демчук, Т. А. Грошовый, О. Н. Леськив, Н. В. Маланчук \\ Тернопольский национальный медицинский университет имени И. Я. Горбачевского мОз Украины \\ pavljukm@tdmu.edu.ua
}

Цель работы. Изучение влияния различного количества некоторых марок лактозы на смену технологических параметров модельных таблеток, полученных прямым прессованием.

Материалы и методы. В работе использовали лактозы моногидрат 200/25, MicroceLac ${ }^{\circledR}$ 100, Ludipress ${ }^{\circledR}$, Cellactose $^{\circledR}$ 80, Pharmatose ${ }^{\circledR}$ DCL-21. Как модельные объекты-вещества использовали кислоту ацетилсалициловую и меторормина гидрохлорид. Массы для таблетирования оценивали по показателям насыпной плотности, плотности после усадки, текучести, коэфриццента Гауснера. Таблетки получали методом прямого прессования на лабораторном таблетпрессе и контролировали их фрармако-технологические свойства.

Результаты и обсуждение. Исследовано влияние различных количеств лактозы моногидрата 200/25, MicroceLac $^{\circledR}$ 100, Ludipress ${ }^{\circledR}$, Cellactose ${ }^{\circledR}$ 80, Pharmatose ${ }^{\circledR}$ DCL-21 на смену технологических показателей массы для таблетирования с кислотой ацетилсалициловой. Лучшую сыпучесть и значение коэффрициента Гауснера имеют те массы, которые содержали Ludipress в количестве $12 \%$, Cellactose 80 в количестве 8 или $10 \%$, Pharmatose DCL-21 в количестве 8 \%. Устойчивость таблеток к раздавливанию и истираемость улучшало введение Pharmatose® DCL-21 или MicroceLac® 100. Использование любого типа лактозы обеспечивало быстрое распадание таблеток ацетилсалициловой кислоты.

Порошок метформина гидрохлорида характеризуется фрармако-технологическими показателями, которые делают невозможным его прямое прессование без вспомогательных веществ. Лучшие значения устойчивости таблеток к раздавливанию и стираемости таблеток получены при введении в их состав 10 \% Cellactose ${ }^{\circledR} 80$ или 8 \% MicroceLac ${ }^{\circledR} 100$.

Выводы. Исследовано влияние различных количеств лактозы моногидрата 200/25, MicroceLac ${ }^{\circledR} 100$, Ludipress $^{\circledR}$, Cellactose ${ }^{\circledR}$ 80, Pharmatose ${ }^{\circledR}$ DCL-21 на изменение технологических показателей таблеток кислоты ацетилсалициловой, а также метсрормина гидрохлорида, полученных прямым прессованием. Улучшение технологических параметров массы для таблетирования и таблеток с кислотой ацетилсалициловой можно достичь при использовании Ludipress в количестве $12 \%$ от массы таблетки, Cellactose 80 в количестве $10 \%$, Pharmatose DCL-21 в количестве 8 \%. Таблетки меторормина с желаемыми значениями устойчивости к раздавливанию и стираемости получены при введении в их состав $10 \%$ Cellactose $^{\circledR} 80$ или 8 \% MicroceLac ${ }^{\circledR} 100$.

Ключевые слова: таблетки; прямое прессование; лактоза; MicroceLac ${ }^{\circledR} 100 ;$ Ludipress ${ }^{\circledR}$; Cellactose ${ }^{\circledR} 80 ;$ Pharmatose $^{\circledR}$ DCL-21.

\section{Список бібліографічних посилань}

1. Дослідження асортименту допоміжних речовин, які використовують у лікарських засобах, зареєстрованих на території України / Лукашів О. І., Демчук М. Б., Гуреєва С. М., Грошовий Т. А. Фармацевтичний часопис. 2013. № 3. С. 50-54.

2. Mangal S., Meiser F., Morton D., Larson I. Particle engineering of excipients for direct compression: understanding the role of material properties. Curr. Pharm. Des. 2015. Vol. 21, Iss.40. P. 5877-5889.
3. Cinnamyl O-Amine functionalized chitosan as a new excipient in direct compressed tablets with improved drug delivery. G. Ren, C. Clancy, T. M. Tamer et al. Int. J. Biol. Macromol. 2019. Vol. 141. P. 936-946.

4. Development of alginate esters as novel multifunctional excipients for direct compression. N. M. SanchezBallester, B. Bataille, R. Benabbas et al. Carbohydrate Polymers. 2020. Vol. 240. P.116280.

5. Neveu A., Janssen P., Lumay G. The flowability of lac-

ISSN 2312-0967. Pharmaceutical review. 2021. № 2 
Фармацевтична технологія, біофармація, гомеопатія Pharmaceutical technology, biopharmacy, homeopathy

tose powders to optimise tableting processes. On Drug Delivery. 2020. Iss.109. P. 58-62.

6. Hebbink G. A., Dickhoff B. H. Application of lactose in the pharmaceutical industry. In: Paques M, Lindner C, editors. Lactose. Elsevier: Academic Press. 2019. P.175-229.

7. Lute S. V., Dhenge R. M., Salman A. D. Twin screw granulation: effects of properties of primary powders. Pharmaceutics. 2018. Vol. 10, Iss. 2. P. 68.

8. Grote S., Kleinebudde P. A comparative study of the influence of alpha-lactose monohydrate particle morphology on granule and tablet properties after roll compaction/dry granulation. Pharmaceutical Development and Technology. 2019. Vol. 24, Iss. 3. P. 314-322.

9. Fara D. A. A comparison of industrial lactose obtained by roller compaction with spray dried lactose and $\alpha$-lactose monohydrate using compression analysis techniques Journal of Excipients and Food Chemicals. 2019. Vol. 10, Iss. 2. P. 41-54.

10. Using spray-dried lactose monohydrate in wet granulation method for a low-dose oral formulation of a paliperidone derivative. W. Huang, Y. Shi, C. Wang et al. Powder Technol. 2013. Vol. 246. P. 379-394.

11. Keleb E. I., Vermeire A., Vervaet C., Remon J. P. Single-step granulation/tabletting of different grades of lactose: A comparison with high shear granulation and compression. Eur. J. Pharm. Biopharm. 2004. Vol. 58. P. 77-82.

12. Akin-Ajani O. D., Odeku O. A., Olumakinde-Oni O. Evaluation of the mechanical and release properties of lactose and microcrystalline cellulose and their binary mixtures as directly compressible excipients in

\section{References}

1. Lukashiv OI, Demchuk MB, Huryeyeva CM, Hroshovyi TA. [Research of the range of excipients used in medicines registered in Ukraine]. Farmatsevt chasop. 2013;3: 50-4. Ukrainian.

2. Mangal S, Meiser F, Morton D, Larson I. Particle engineering of excipients for direct compression: understanding the role of material properties. Curr Pharm Des. 2015;21(40): 5877-89.

3. Ren G, Clancy C, Tamer TM, Schaller B, Walker GM, Collins MN. Cinnamyl O-amine functionalized chitosan as a new excipient in direct compressed tablets with improved drug delivery. Int J Biol Macromol. 2019;141: 936-46.

4. Sanchez-Ballester NM, Bataille B. Benabbas R, Alonso $B$, Soulairol, I. Development of alginate esters as novel multifunctional excipients for direct compression. Carbohydr Polym. 2020;240: 116280

5. Neveu A, Janssen P, Lumay G. The flowability of lactose powders to optimise tableting processes. On Drug Delivery. 2020;109: 58-62.

6. Hebbink GA, Dickhoff BH. Application of lactose in the pharmaceutical industry. Lactose. Elsevier: Academic Press; 2019: 175-229.

7. Lute SV, Dhenge RM, Salman AD. Twin Screw granulation: Effects of properties of primary powders. Pharma- paracetamol tablets. Journal of Excipients and Food Chemicals. 2020.Vol.11, Iss.2. P. 42-52.

13. Meggle Excipients \& Technology, Technical Brochure MicroceLac $® 100$. - Access mode : https://www.meggle-pharma.com/en/lactose/13-microcelac-100.html.

14. Mustarichie R., Gozali D., Priambodo D. Dissolution profile of Ambroxol $\mathrm{HCL}$ tablet with additional variations of Ludipress $®$ and lactose using the direct press method. International Journal of Applied Pharmaceutics. 2020. Vol.12, Iss.3. P. 62-66.

15. Basf Chemical Company Ludipress ${ }^{\circledR}$ Brochure. - Access mode : https://pharmaceutical.basf.com/global/ en/drug-formulation/products/ludipress.html

16. Performance evaluation of a novel biosourced coprocessed excipient in direct compression and drug release. R. Benabbas, N. M. Sanchez-Ballester, A. Aubert et al. Polymers. 2012. Vol. 13, Iss. 6. P. 988.

17. Meggle Excipients \& Technology, Technical Brochure Cellactose ${ }^{\circledR}$ 80. - Access mode : https://www.megglepharma.com/en/lactose/12-cellactose-80.html

18. DMV excipient guide 3.2.1. - Access mode : http://www. phexcom.cn/UploadFiles/20130217102234_5017.pdf

19. The compressibility and compactibility of different types of lactose. I. Ilić, Jr. P. Kása, R. Dreu, et al. Drug Development and Industrial Pharmacy. 2009. Vol. 35, Iss.10. P. 1271-1280.

20. Державна Фармакопея України: в 3 т. / Державне підприємство «Український науковий срармакопейний центр якості лікарських засобів». - 2-ге вид. - Харків : Державне підприємство «Український науковий фрармакопейний центр якості лікарських засобів», 2014. Т. 1. 1128 с.

ceutics. 2018;10(2): 68

8. Grote S, Kleinebudde P. A comparative study of the influence of alpha-lactose monohydrate particle morphology on granule and tablet properties after roll compaction/dry granulation. Pharmaceutical Development and Technology. 2019;24(3): 314-22.

9. Fara DA. A comparison of industrial lactose obtained by roller compaction with spray dried lactose and a-lactose monohydrate using compression analysis techniques. JEFC. 2019;10(2): 41-54.

10. Huang $W$, Shi $Y$, Wang $C$, Yu K, Sun F, Li Y. Using spray-dried lactose monohydrate in wet granulation method for a low-dose oral formulation of a paliperidone derivative. Powder Technol. 2013;246: 379-94.

11. Keleb El, Vermeire A, Vervaet C, Remon, JP. Singlestep granulation/tabletting of different grades of lactose: A comparison with high shear granulation and compression. Eur J Pharm Biopharm. 2004;58: 77-82.

12. Akin-Ajani OD, Odeku OA, Olumakinde-Oni O. Evaluation of the mechanical and release properties of lactose and microcrystalline cellulose and their binary mixtures as directly compressible excipients in paracetamol tablets. JEFC. 2020;11(2): 42-52.

13. Meggle Excipients \& Technology, Technical Brochure MicroceLac $® 100$. [Electronic resource]. Available from:

ISSN 2312-0967. Фармацевтичний часопис. 2021. № 2 
https://www.meggle-pharma.com/en/lactose/13-microcelac-100.html.

14. Mustarichie R, Gozali D, Priambodo D. Dissolution profile of Ambroxol HCL tablet with additional variations of Ludipress ${ }^{\circledR}$ and lactose using the direct press method. International Journal of Applied Pharmaceutics. 2020;12(3): 62-6.

15. Basf Chemical Company Ludipress ${ }^{\circledR}$ Brochure. [Electronic resource]. Available from: https://pharmaceutical.basf. com/global/en/drug-formulation/products/ludipress.html

16. Benabbas R, Sanchez-Ballester NM, Aubert A, Sharkawi T, Bataille B, Soulairol I. Performance evaluation of a novel biosourced co-processed excipient in direct compression and drug release. Polymers. 2012;13(6): 988.

17. Meggle Excipients \& Technology, Technical Brochure Cellactose ${ }^{\circledR}$ 80. [Electronic resource]. Available from:
Фармацевтична технологія, біофармація, гомеопатія Pharmaceutical technology, biopharmacy, homeopathy

https://www.meggle-pharma.com/en/lactose/12-cellactose-80.html

18. DMV excipient guide 3.2.1. [Electronic resource]. Available from: http://www.phexcom.cn/UploadFiles/20130217102234_5017.pdf

19. Ilić I, Kása JrP, Dreu R, Pintye-Hódi K, Srčič S. The compressibility and compactibility of different types of lactose. Drug development and industrial pharmacy. 2009;35(10): 1271-80.

20. The State Pharmacopoeia of Ukraine: 1 vol. Kharkiv: Ukrainian Scientific Pharmacopoeia Center of Quality of Medicinal Products. Ed.2. Vol.1 [Державна Фармакопея України: в 3 т./ Державне підприємство «Український науковий фармакопейний центр якості лікарських засобів». - 2-е вид.]: Kharkiv: Ukrainian Scientific Pharmacopoeia Center of Quality of Medicinal Products; 2015. Ukrainian.

\section{Відомості про авторів}

Демчук М. Б. - канд. фрармац. наук, доцент кафедри управління та економіки фрармації з технологією ліків, Тернопільський національний медичний університет імені І. Я. Горбачевського МОЗ України, Тернопіль, Україна. E-mail: pavljukm@tdmu.edu.ua, ORCID 0000-0002-9105-2302.

Грошовий Т. А. - д. фрармац. наук, профресор, завідувач кафедри управління та економіки фрармації 3 технологією ліків, Тернопільський національний медичний університет імені І. Я. Горбачевського МОЗ України, Тернопіль, Україна. E-mail: grochovuy@ukr.net, ORCID 0000-0002-6427-2158.

Леськів О. М. - студентка фрармацевтичного фракультету, магістрант кафедри управління та економіки фрармації 3 технологією ліків Тернопільського національного медичного університету імені І. Я. Горбачевського МОЗ України, Тернопіль, Україна. E-mail: leskiv_olmy@tdmu.edu.ua

Маланчук Н. В. - провізор-інтерн, Тернопільський національний медичний університет імені І. Я. Горбачевського MO3 України, Тернопіль, Україна. E-mail: nadia700555@gmail.com, ORCID 0000- 0002-0175-7502.

\section{Information about the authors}

Demchuk M. B. - PhD (Pharmacy), Associate Professor of the Department of Pharmacy Management, Economics and Technology, I. Horbachevsky Ternopil National Medical University, Ternopil, Ukraine. E-mail: pavljukm@tdmu.edu.ua, ORCID 0000-0002-9105-2302.

Hroshovyi T. A. - DSc (Pharmacy), Professor, Head of the Department of Pharmacy Management, Economics and Technology, I. Horbachevsky Ternopil National Medical University, Ternopil, Ukraine. E-mail: grochovuy@ukr.net, ORCID 00000002-6427-2158.

Leskiv O. M. - student of Pharmaceutical Faculty, I. Horbachevsky Ternopil National Medical University, Ternopil, Ukraine. E-mail: leskiv_olmy@tdmu.edu.ua

Malanchuk N. V. - pharmacist-intern, I. Horbachevsky Ternopil National Medical University, Ternopil, Ukraine. E-mail: nadia700555@gmail.com, ORCID 0000-0002-0175-7502. 